\title{
Allelopathic Effect of Crambe (Crambe abyssinica) Extract on Corn Seedlings
}

\author{
Bruna de Villa ${ }^{1}$, Reginaldo Ferreira Santos ${ }^{1}$, Deonir Secco $^{1}$, Jair Antonio Cruz Siqueira ${ }^{1}$, Luciene Kazue Tokura ${ }^{1}$, \\ Maritane Prior ${ }^{1}$, Alessandra Mayumi Tokura Alovisi ${ }^{2}$, Laura Luana Foltz ${ }^{1}$, Chaiane Bassegio ${ }^{1}$, \\ Willian Silva Melo ${ }^{1}$, Mauricio Antonio Pauly ${ }^{1}$, Leonardo da Silva Reis ${ }^{1}$, Matheus Rodrigues Savioli ${ }^{1}$, \\ Laís Fernanda Juchem do Nascimento $^{1} \&$ Soni Willian Haupenthal ${ }^{1}$ \\ ${ }^{1}$ State University of West Paraná, Cascavel, Paraná, Brazil \\ ${ }^{2}$ Post-Graduation Program in Agronomy, Federal University of Grande Dourados, Dourados, Mato Grosso do \\ Sul, Brazil \\ Correspondence: Bruna de Villa, State University of West Paraná, Rua Universitária, 2069-Jardim Universitário, \\ CEP: 85819-110, Cascavel, Paraná, Brazil. Tel: 55-453-220-3151. E-mail: bruna.devilla.58@hotmail.com
}

Received: December 28, 2018

Accepted: February 13, 2019 Online Published: April 15, 2019

doi:10.5539/jas.v11n5p314

URL: https://doi.org/10.5539/jas.v11n5p314

\begin{abstract}
The crambe crop is an interesting option for the production of biodiesel, mainly due to the high oil content (35\%) and the corn one of the most implanted crops in Brazil. Thus, the objective of this work was to evaluate the allelopathic effect of crambe in the initial development of maize. The experiment was carried out in the laboratory of seed and plant evaluation (LASP) and laboratory of soil physics (LAFIS) of UNIOESTE-Cascavel. The seeds of corn with germination of $93.5 \%$ were submitted to four concentrations plus the control in the different parts of the crambe plant, where the growth and mass of corn were valued. The experimental design was completely randomized with 4 replicates per treatment. The statistical analysis consisted of analysis of variance and the means of the treatments were compared by the Tukey test at $5 \%$ of significance. The extract of the whole crambe plant stimulated aerial length, root length, fresh and dry mass of corn shoot. Root, stem and leaf extracts inhibited the initial development of maize in relation to growth and fresh and dry shoot mass.
\end{abstract}

Keywords: Allelopathy, aqueous extract, Zea mays

\section{Introduction}

Crambe (Crambe abyssinica) belongs to the brassicaceae family and originates in the Mediterranean region. It is a forage that has high oil content in its seed (approximately 35\%). It is highly resistant to drought after settlement and tolerant to frost. It presents good yield in the dry season (winter crop) and is an alternative for the safrinha corn (Pitol, 2008; Falasca et al., 2010; Pitol et al., 2010).

With the advent of biodiesel, crambe emerges as an alternative for complementing vegetable oil production, with many challenges still ahead, given that it is a poorly researched crop in Brazil and represents a new field of study for researchers and students (Kunz et al., 2012; Wang et al., 2000).

Studies, such as those of Broch and Ranno (2011), show that with the use of the crambe crop prior to corn, there is an increase in sack yield per hectare compared to other types of cover.

Brazil is considered the third largest producer of corn, with a production of 30,462,000 metric tons. The southern part of Brazil is considered the most productive region for corn, with a production of 13,992,700 metric tons, in the 2016/2017 crop. As the state of Paraná accounts for 4,692,700 metric tons in yield (CONAB, 2018; Formigheiri et al., 2018), it is essential to study the allelopathic effect of crambe on this crop.

The term allelopathy was first used by Hans Molish in 1937 to describe the positive and negative chemical interactions of plants and microorganisms. Allelopathy refers to the positive or negative effects of one plant on another, through the release of chemical compounds (allelochemicals) by leaching of parts of the plant, root exudates, volatilization or leaf decomposition (Ferreira \& Borghetti, 2004), given that the incorporation of crop remains may perform an allelopathic function due to chemical compounds, in which all plants produce secondary metabolites, which vary in quality and quantity from species to species and from one crop cycle to another (Vyvyan, 2002; Menegusso \& Simonetti, 2015). 
Thus, the purpose of this study was to evaluate the effects of the crambe aqueous extract on the initial development of the corn crop based on the hypothesis that the crambe extract increases shot and root growth in the initial development of the corn crop.

\section{Material and Methods}

\subsection{Location of the Experiment and Treatments}

The experiment was carried out in 2018 at the Seed and Plant Evaluation Laboratory (LASP) and the Soil Physics Laboratory (LAFIS), at the State University of Western Paraná (UNIOESTE). The experiment consisted of four treatments with crambe, with four concentrations per treatment, in which each concentration had four replicates, according to the methodology proposed by the Seed Analysis Regulation (RAS, 2009).

The treatments were T1: Whole plant; T2: Root; T3: Stem; and T4: Leaf. Corn seeds were submitted to concentrations of $5 \%, 10 \%, 15 \%$ and $20 \%$, plus the control.

The crambe plants were collected at flowering time in the experimental area of the Paraná Agronomic Institute (IAPAR), located in Santa Tereza do Oeste, PR, Brazil. For treatment T1 (whole plant), the plants were cut at a length of about $5 \mathrm{~cm}$, washed in distilled water, and dried in the wind. After this procedure, 60 grams of plants were weighed in $300 \mathrm{ml}$ of distilled water and mixed in a blender. They were then strained in an industrial sieve and packed in PET bottles, which were sealed, wrapped in aluminum foil and kept in a refrigerator for a period of seven days.

In $\mathrm{T} 2$, the roots were cut at a length of about $5 \mathrm{~cm}$, also at a concentration of $60 \mathrm{~g}$ of plants to $300 \mathrm{ml}$ of distilled water, and were packed directly in PET bottles, which were subsequently kept in a refrigerator.

In T3, the stems were cut at a length of about $5 \mathrm{~cm}$, also in a concentration of $60 \mathrm{~g}$ of plants to $300 \mathrm{ml}$ of distilled water, and were packed directly in a PET bottle, which was later kept in a refrigerator.

In $\mathrm{T} 4$, the leaves were cut at a length of about $5 \mathrm{~cm}$, also in a concentration of $60 \mathrm{~g}$ of plants to $300 \mathrm{ml}$ of distilled water, and were packed directly in a PET bottle, which was later kept in a refrigerator.

The corn seeds with germination of $93.5 \%$ were submitted to the four treatments above, and each treatment had 4 different concentrations: $5 \%, 10 \%, 15 \%$, and $20 \%$.

In this study, the Germitest paper was moistened with 2.5 times its extract weight, and 11 corn seeds were conditioned for each replicate. The attributes evaluated were the shoot growth, root system growth, shoot fresh mass, root fresh mass, shoot dry mass, and root dry mass. The samples were kept for a period of seven days under controlled temperature in a germination greenhouse. A cut-off point was established for all readings, and the samples weighed on a scale of 4 decimal places, and measurements of the end points of the seedling were taken by means of a graduated ruler.

\subsection{Statistical Analysis of the Data}

The mean values obtained were compared by the Tukey test, considering the level of significance of $\alpha=5 \%$. Statistical analyses were performed using the SISVAR statistical analysis program.

\section{Results and Discussion}

Tables 1, 2, 3, 4, 5 and 6 present the mean values of shoot length, root length, shoot fresh mass, root fresh mass, shoot dry mass and root dry mass of corn under the effects of different concentrations of crambe roots, whole plants, stems, and leaves.

In Table 1, it can be observed that there was a significant difference between the different plant parts at $5 \%, 10 \%$, $15 \%$ and $20 \%$ concentration, whereas for $5 \%$, the whole-plant extract had the highest value $(26.359 \mathrm{~cm})$, differing from treatments with stem $(12.3295 \mathrm{~cm})$ and leaf $(13.926 \mathrm{~cm})$, which did not differ from each other, and differing from the root extract $(9.876 \mathrm{~cm})$, which presented the lowest value.

For the $10 \%$ concentration, it can be observed that the same effect occurred, the whole-plant extract having the highest value $(11.838 \mathrm{~cm})$, differing from stem $(15.155 \mathrm{~cm})$ and leaf $(15.093 \mathrm{~cm})$, both of which did not differ from each other, and differing from the root extract, which presented the lowest value $(11.838 \mathrm{~cm})$.

For the $15 \%$ concentration, the whole-plant treatment $(26.144 \mathrm{~cm})$ differed from stem $(13.084 \mathrm{~cm})$ and leaf $(14.246 \mathrm{~cm})$ treatments, which did not differ at $5 \%$ significance, also differing from root extract $(10.767 \mathrm{~cm})$.

Finally, for the $20 \%$ concentration, it can be observed that the whole-plant extract $(27.861 \mathrm{~cm})$ differed from the leaf $(14.949 \mathrm{~cm})$ and root $(12.264 \mathrm{~cm})$ treatments, as well as from the stem treatment $(13.880 \mathrm{~cm})$, which did not present difference between leaf and root extracts. 
Also, in Table 1, it can be observed that all the plant parts presented significant difference for the different concentrations. For the root extract, the control $(19.531 \mathrm{~cm})$ presented the highest value, differing from the $5 \%$ $(9.876 \mathrm{~cm})$ and $20 \%(12.264 \mathrm{~cm})$ concentration, as well as from the $10 \%(11.838 \mathrm{~cm})$ and $15 \%(10.767 \mathrm{~cm})$ concentration, which did not differ from the $5 \%$ and $20 \%$ concentrations.

As for the whole plant, it can be observed that the control $(19.531 \mathrm{~cm})$ presented the highest value, differing from all other concentrations, which did not differ among themselves, presenting values of $26.359 \mathrm{~cm}, 26.255$ $\mathrm{cm}, 26.144 \mathrm{~cm}$ and $17.861 \mathrm{~cm}$, respectively.

Regarding the stem extract, it can be observed that the control $(19.531 \mathrm{~cm})$ presented the highest value, differing from the $5 \%(12.325 \mathrm{~cm})$ and $10 \%(15.155 \mathrm{~cm})$ concentrations, as well as the $15 \%(13.084 \mathrm{~cm})$ and $20 \%(13.880$ $\mathrm{cm}$ ) concentrations, which did not differ from each other, when compared to $5 \%$ and $10 \%$.

As for the leaf extract, it can be observed that the control $(19.531 \mathrm{~cm})$ had the highest value, differing from all other concentrations with values of $13.926 \mathrm{~cm}, 15.093 \mathrm{~cm}, 14.246 \mathrm{~cm}$ and $14.949 \mathrm{~cm}$, respectively. It can be observed that the whole-plant extract is the one that most stimulates shoot length when compared with the other parts of the plants. The results differ from those observed by Menegusso and Simonetti (2015), who found that increasing the concentration of crambe extracts resulted in decrease in shot length and are in accordance with those found by Kunz et al. (2012), who found that the $20 \%$ concentration of crambe extract resulted in millet root growth.

Table 1. Mean values of shoot length under different concentrations of each part of the crambe plant

\begin{tabular}{lllll}
\hline Shoot length $(\mathrm{cm})$ & \multicolumn{5}{l}{} \\
\hline Concentration $(\%)$ & Root & Plant & Stem & Leaf \\
\hline 0 & $19.531 \mathrm{a}$ & $19.531 \mathrm{~b}$ & $19.531 \mathrm{a}$ & $19.531 \mathrm{a}$ \\
5 & $9.876 \mathrm{cC}$ & $26.359 \mathrm{aA}$ & $12.325 \mathrm{c} \mathrm{B}$ & $13.926 \mathrm{bB}$ \\
10 & $11.838 \mathrm{bcC}$ & $26.255 \mathrm{aA}$ & $15.155 \mathrm{~b} \mathrm{~B}$ & $15.093 \mathrm{bB}$ \\
15 & $10.767 \mathrm{bcC}$ & $26.144 \mathrm{aA}$ & $13.084 \mathrm{bcB}$ & $14.246 \mathrm{bB}$ \\
20 & $12.264 \mathrm{bC}$ & $27.861 \mathrm{aA}$ & $13.880 \mathrm{bcBC}$ & $14.949 \mathrm{bB}$ \\
Mean & 17.107 & & & \\
DMS Concentration & 2.311 & & & \\
DMS Treatment & 2.171 & & & \\
CV & 6.79 & & & \\
\hline
\end{tabular}

Note. Means followed by the same capital letters on the line and lower case in the column do not differ by Tukey test at 5\% significance. DMS: minimal significant differences test.

It can be observed in Table 2 that the different plant parts used as extract differed in the concentrations of 5\%, $10 \%, 15 \%$ and $20 \%$. In all cases, the one with the highest value was whole-plant extract, differing from the other parts of the plant, which presented no significant difference among them at $5 \%$ of significance. The whole-plant extract at $5 \%$ concentration presented a value of $24.562 \mathrm{~cm}$, differing from root, stem and leaf, which reached values of $17.544 \mathrm{~cm}, 17.0588 \mathrm{~cm}$ and $17.544 \mathrm{~cm}$, respectively. 
Table 2. Mean values of root length under different concentrations of each part of the crambe plant

\begin{tabular}{lllll}
\hline Root length $(\mathrm{cm})$ & & & \\
\hline Concentration $(\%)$ & Root & Plant & Stem & Leaf \\
\hline 0 & 19.263 & $19.263 \mathrm{~b}$ & 19.263 & 19.263 \\
5 & $17.544 \mathrm{~B}$ & $24.562 \mathrm{aA}$ & $17.058 \mathrm{~B}$ & $17.544 \mathrm{~B}$ \\
10 & $17.940 \mathrm{~B}$ & $24.487 \mathrm{aA}$ & $17.843 \mathrm{~B}$ & $17.940 \mathrm{~B}$ \\
15 & $16.317 \mathrm{~B}$ & $23.308 \mathrm{aA}$ & $17.460 \mathrm{~B}$ & $16.317 \mathrm{~B}$ \\
20 & $17.392 \mathrm{~B}$ & $23.673 \mathrm{aA}$ & $18.081 \mathrm{~B}$ & $17.392 \mathrm{~B}$ \\
\hdashline Mean & 19.095 & & & \\
DMS Concentration & 3.409 & & & \\
DMS Treatment & 3.203 & & \\
CV & 8.97 & & & \\
\hline
\end{tabular}

Note. Means followed by the same capital letters on the line and lower case in the column do not differ by Tukey test at 5\% significance. DMS: minimal significant differences test.

The same occurred for the $10 \%$ concentration, in which the whole-plant extract presented a value of $24.487 \mathrm{~cm}$, differing from the other treatments, which reached values of $17.940 \mathrm{~cm}, 17.843 \mathrm{~cm}$, and $17.940 \mathrm{~cm}$. As for the $15 \%$ concentration, the whole-plant treatment presented a value of $23.308 \mathrm{~cm}$, differing from the other treatments, which reached values of $16.317 \mathrm{~cm}, 17.460 \mathrm{~cm}$ and $16.317 \mathrm{~cm}$, respectively. In turn, in the $20 \%$ concentration, the whole-plant extract $(23.673 \mathrm{~cm})$ differed from the root $(17.392 \mathrm{~cm})$, stem $(18.081 \mathrm{~cm})$ and leaf $(17.392 \mathrm{~cm})$ treatments.

Regarding the different concentrations, it can be observed that there was only a significant difference for the whole-plant extract. The control treatment had the lowest value $(19.263 \mathrm{~cm})$, differing from the other treatments, which did not differ from each other, reaching values of $24.562 \mathrm{~cm}, 24.487 \mathrm{~cm}, 23.308 \mathrm{~cm}$, and $23.673 \mathrm{~cm}$, respectively. This shows that the use of the extract stimulates root growth, and there was no difference between the concentrations, as opposed to the results found by Renosto et al. (2014), who showed that crambe extract stimulated root growth at $5 \%$ concentration, while inhibiting it at $10 \%$, but did not influence shoot growth. The results are in accordance with Kunz et al. (2012), which observed root millet inhibition at the $10 \%$ concentration of the crambe leaf extract.

In Table 3, it can be observed that there was a difference between the different parts of the plant used as extract for the concentrations of $5 \%, 10 \%, 15 \%$ and $20 \%$, in which the whole-plant treatment presented the highest value, differing from the root extract, which presented the lowest value, and the stem and leaf extracts, which did not differ from each other. The results were different only for the $20 \%$ concentration, in which the plant extract also presented the highest value and differed from all other treatments. Other treatments, however, showed no difference.

For the $5 \%$ concentration, it can be observed that the whole-plant extract stands out, with a value of $1.040 \mathrm{~cm}$, differing from the root extract $(0.486 \mathrm{~g})$, as well as from the stem $(0.598 \mathrm{~g})$ and leaf $(0.665 \mathrm{~g})$ extracts, which did not differ from each other. For the $10 \%$ concentration, the whole-plant extract $(1.073 \mathrm{~g})$ differed from the root extract $(0.575 \mathrm{~g})$, as well from the stem $(0.707 \mathrm{~g})$ and leaf $(0.690 \mathrm{~g})$ treatments, which did not differ from each other.

The same was observed for the $15 \%$ concentration, in which the whole-plant extract $(1.046 \mathrm{~g})$ had the highest value, differing from root extract $(0.521 \mathrm{~g})$, as well as from the stem $(0.645 \mathrm{~g})$ and leaf $(0.659 \mathrm{~g})$ treatments, which do not differ from each other. At the $20 \%$ concentration, the whole-plant extract $(1.125 \mathrm{~g})$ presented the highest value and differed from the other treatments, which did not present significant differences among them at $5 \%$ of significance, reaching values of $0.590 \mathrm{~g}, 0.657 \mathrm{~g}$, and $0.657 \mathrm{~g}$, respectively.

Regarding the different concentrations, it can be observed that for the root, stem and leaf extracts, the control treatment presented the highest value, differing from the other concentrations, which did not differ from each other. For whole-plant extract, the lowest value was presented by the control treatment, differing from all other concentrations, which did not differ from each other.

For the root extract, the control value was $0.871 \mathrm{~g}$, differing from the $5 \%, 10 \%, 15 \%$ and $20 \%$ concentrations, which reached values of $0.486 \mathrm{~g}, 0.575 \mathrm{~g}, 0.521 \mathrm{~g}$, and $0.590 \mathrm{~g}$, respectively. For the stem extract, the control value was $0.871 \mathrm{~g}$, while the other concentrations reached $0.598 \mathrm{~g}, 0.707 \mathrm{~g}, 0.645 \mathrm{~g}$, and $0.657 \mathrm{~g}$, respectively. In turn, in leaf extract, the control treatment had a value of $0.871 \mathrm{~g}$, while the other concentrations were $0.665 \mathrm{~g}$, 
$0.690 \mathrm{~g}, 0.659 \mathrm{~g}$, and $0.657 \mathrm{~g}$, respectively. For the whole-plant extract, the lowest value was $0.871 \mathrm{~g}$, differing from the other concentrations, which reached values of $1.040 \mathrm{~g}, 1.073 \mathrm{~g}, 1.046 \mathrm{~g}$, and $1.125 \mathrm{~g}$, respectively.

Table 3. Mean values of fresh shoot mass under different concentrations of each part of the crambe

\begin{tabular}{|c|c|c|c|c|}
\hline \multicolumn{5}{|l|}{ Shoot fresh mass $(\mathrm{g})$} \\
\hline Concentration (\%) & Root & Plant & Stem & Leaf \\
\hline 0 & $0.871 \mathrm{a}$ & $0.871 \mathrm{~b}$ & $0.871 \mathrm{a}$ & $0.871 \mathrm{a}$ \\
\hline 5 & $0.486 \mathrm{bC}$ & $1.040 \mathrm{aA}$ & $0.598 \mathrm{bB}$ & $0.665 \mathrm{bB}$ \\
\hline 10 & $0.575 \mathrm{bC}$ & $1.073 \mathrm{aA}$ & $0.707 \mathrm{bB}$ & $0.690 \mathrm{bB}$ \\
\hline 15 & $0.521 \mathrm{bC}$ & $1.046 \mathrm{aA}$ & $0.645 \mathrm{bB}$ & $0.659 \mathrm{bB}$ \\
\hline 20 & $0.590 \mathrm{bB}$ & $1.125 \mathrm{aA}$ & $0.657 \mathrm{bB}$ & $0.657 \mathrm{bB}$ \\
\hline Mean & 0.761 & & & \\
\hline DMS Concentration & 0.115 & & & \\
\hline DMS Treatment & 0.108 & & & \\
\hline $\mathrm{CV}$ & 7.59 & & & \\
\hline
\end{tabular}

Note. Means followed by the same capital letters on the line and lower case in the column do not differ by Tukey test at 5\% significance. DMS: minimal significant differences test.

It can be observed in Table 4 that there was a significant difference only between the different parts of plants used as extract at the $5 \%$ concentration, in which there was a significant difference between the root $(0.549 \mathrm{~g})$ and stem $(0.558 \mathrm{~g})$ when compared to the whole-plant extract $(0.437 \mathrm{~g})$, while the leaf extract $(0.456 \mathrm{~g})$ did not differ among treatments. It can be observed that the whole-plant extract reduces the root fresh mass of when compared with the other parts of the plants.

Table 4. Mean values of fresh root part mass under different concentrations of each part of the crambe plant

\begin{tabular}{lllll}
\hline Root fresh mass $(\mathrm{g})$ & & & & \\
\hline Concentration $(\%)$ & Root & Plant & Stem & Leaf \\
\hline 0 & 0.458 & 0.458 & 0.458 & 0.458 \\
5 & $0.549 \mathrm{~A}$ & $0.437 \mathrm{~B}$ & $0.558 \mathrm{~A}$ & $0.456 \mathrm{AB}$ \\
10 & 0.512 & 0.413 & 0.506 & 0.462 \\
15 & 0.494 & 0.418 & 0.499 & 0.435 \\
20 & 0.512 & 0.461 & 0.459 & 0.415 \\
Mean & 0.471 & & & \\
DMS Concentration & 0.109 & & & \\
DMS Treatment & 0.103 & & & \\
CV & 11.67 & & &
\end{tabular}

Note. Means followed by the same capital letters on the line and lower case in the column do not differ by Tukey test at 5\% significance. DMS: minimal significant differences test.

In Table 5, it can be observed that there was a significant difference between the different parts of the plants at the $5 \%, 10 \%, 15 \%$ and $20 \%$ concentrations. At the $5 \%$ concentration, the whole-plant extract $(0.075 \mathrm{~g})$ presented the highest value, differing from the leaf $(0.048 \mathrm{~g})$ and root $(0.035 \mathrm{~g})$ extract, as well as from the stem extract $(0.042 \mathrm{~g})$, which differed only from the whole-plant extract. The same was observed for the $10 \%$ concentration, in which the whole-plant extract $(0.079 \mathrm{~g})$ presented the highest value, differing from leaf $(0.049 \mathrm{~g})$ and root $(0.041 \mathrm{~g})$ extract, as well as stem extract $(0.047 \mathrm{~g})$, which differed only from the whole-plant extract. For the $20 \%$ concentration, the whole-plant extract $(0.085 \mathrm{~g})$ presented the highest value, differing from leaf $(0.05 \mathrm{~g})$ and root $(0.041 \mathrm{~g})$ extract, as well as from the stem extract $(0.048 \mathrm{~g})$, which differed only from the whole-plant extract. In contrast, at the $15 \%$ concentration, the whole-plant extract $(0.076 \mathrm{~g})$ presented the highest value, differing from the root treatment $(0.041 \mathrm{~g})$, as well as from stem $(0.046 \mathrm{~g})$ and leaf $(0.048 \mathrm{~g})$ treatments, which did not differ from each other. 
Table 5. Mean values of the dry mass of the part of the aerial part, under different concentrations of each part of the crambe plant

\begin{tabular}{lllll}
\hline Shoot dry mass $(\mathrm{g})$ & & & & \\
\hline Concentration $(\%)$ & Root & Plant & Stem & Leaf \\
\hline 0 & $0.061 \mathrm{a}$ & $0.061 \mathrm{c}$ & $0.061 \mathrm{a}$ & $0.061 \mathrm{a}$ \\
5 & $0.035 \mathrm{bC}$ & $0.075 \mathrm{bA}$ & $0.042 \mathrm{bBC}$ & $0.048 \mathrm{bB}$ \\
10 & $0.041 \mathrm{bC}$ & $0.079 \mathrm{abA}$ & $0.047 \mathrm{bBC}$ & $0.049 \mathrm{bB}$ \\
15 & $0.038 \mathrm{bC}$ & $0.076 \mathrm{bA}$ & $0.046 \mathrm{bB}$ & $0.048 \mathrm{bB}$ \\
20 & $0.041 \mathrm{bC}$ & $0.085 \mathrm{aA}$ & $0.048 \mathrm{bBC}$ & $0.05 \mathrm{bB}$ \\
\hdashline Mean & 0.055 & & & \\
DMS Concentration & 0.008 & & & \\
DMS Treatment & 0.008 & & & \\
CV & 7.54 & & & \\
\hline
\end{tabular}

Note. Means followed by the same capital letters on the line and lower case in the column do not differ by Tukey test at 5\% significance. DMS: minimal significant differences test.

Regarding the different concentrations for both the root extract and the stem and leaf extract, the control group presented the highest value, differing from all other concentrations, which did not show any significant difference between them. In the whole-plant extract, the control treatment $(0.061 \mathrm{~g})$ presented the lowest value, differing from the $5 \%(0.075 \mathrm{~g})$ and $15 \%(0.076 \mathrm{~g})$ concentrations, as well as the $20 \%(0.085 \mathrm{~g})$ and $10 \%(0.079$ g) concentrations, which differed only from the control treatment.

For the root extract, the control value was $0.061 \mathrm{~g}$, differing from the $5 \%, 10 \%, 15 \%$ and $20 \%$ concentrations, which reached values of $0.035 \mathrm{~g}, 0.041 \mathrm{~g}, 0.038 \mathrm{~g}$, and $0.041 \mathrm{~g}$, respectively. For the stem extract, the control treatment presented a value of $0.061 \mathrm{~g}$, differing from the other concentrations, which reached values of $0.042 \mathrm{~g}$, $0.047 \mathrm{~g}, 0.046 \mathrm{~g}$, and $0.048 \mathrm{~g}$, respectively. The leaf extract reached a value of 0.061 , while control treatment differed from the other treatments, which reached values of $0.048 \mathrm{~g}, 0.049 \mathrm{~g}, 0.048 \mathrm{~g}$, and $0.05 \mathrm{~g}$, respectively. It can be observed that the whole-plant extract is the one that most stimulates shoot length when compared with the other parts of the plants.

In Table 6 it can be observed that there was no significant difference between the different plant parts used for the extract, as well as in the different concentrations for the root dry mass.

Table 6. Mean values of the dry mass of the root part, under different concentrations of each part of the crambe plant

\begin{tabular}{lllll}
\hline Root dry mass $(\mathrm{g})$ & \multicolumn{3}{l}{} \\
\hline Concentration $(\%)$ & Root & Plant & Stem & Leaf \\
\hline 0 & 0.053 & 0.053 & 0.053 & 0.053 \\
5 & 0.046 & 0.054 & 0.054 & 0.043 \\
10 & 0.045 & 0.044 & 0.043 & 0.044 \\
15 & 0.044 & 0.046 & 0.048 & 0.044 \\
20 & 0.046 & 0.055 & 0.044 & 0.043 \\
Mean & 0.048 & & & \\
DMS Concentration & 0.012 & & & \\
DMS Treatment & 0.012 & & \\
CV & 13.16 & & \\
\hline
\end{tabular}

Note. Means followed by the same capital letters on the line and lower case in the column do not differ by Tukey test at 5\% significance. DMS: minimal significant differences test.

These results are in accordance with those found by Vyvyan (2002) and Sampietro et al. (2006), who stated that allelopathy can inhibit or stimulate seed germination. The results, however, differ from those found by Kunz et al. (2012) who conducted experiments with crambe leaf and stem extract on millet (Pennisetum glaucum) and 
did not find any effect of the extract on the germination and development of the shoot of seeds and seedlings, but rather only on radicle length.

According to Spiassi et al. (2011), it is common to cultivate the main crop on the straw of the preceding crop, but this straw may have some influence on the main crop by releasing exudates and organic compounds.

Fortes et al. (2011) used crambe straw on crop development and found that it had an inhibitory effect on shoot growth and root and dry mass of corn seedlings, reporting that this plant is sensitive to said straw. Similar results were found by Spiassi et al. (2011), who noted that crambe straw provided a reduction in shoot length and root and shoot dry mass of corn seedlings, while corn seedlings originating from the treatment with crambe straw reduced root growth by $51.60 \%$ in relation to the control treatment.

The results also agree with those of Pereira and Simonetti (2014), who carried out experiments with extracts from different parts of the crambe plant on the germination and development of soybeans (Glycine max) and noted that crambe fruit extract influenced the germination and development of normal seedlings of said crop.

According to Ferreira \& Borghetti (2004), plant growth is more sensitive to allelochemicals than germination, due to the action of the allelochemicals on membrane bonds of the recipient plant (corn) or their penetration in its cells, in a way that changes its metabolism.

\section{Conclusion}

The whole-plant extract stimulated shoot length, root length and shoot fresh and dry mass of the corn seedlings. Root, stem and leaf extracts inhibited the initial development of corn in terms of growth and shoot fresh and dry mass.

\section{References}

Broch, D. L., \& Ranno, S. K. (2011). Tecnologia e Produção: Soja e Milho 2011/2012: Fertilidade do Solo, Adubação e Nutrição da Cultura do Milho. Fundação MS.

CONAB (Companhia Nacional de Abastecimento). (2018). Acompanhamento da safra Brasileira, v.5-Safra 2017/2018-n.6. Sexto levantamento, Março.

Falasca, S. L., Flores, N., Lamas, M. C., Carballo, S. M., \& Anschau, A. (2010). Crambe abyssinica: An almost unknown crop with a promissory future to produce biodiesel in Argentina. International Journal of Hydrogen Energy, 35, 5808-5812. https://doi.org/10.1016/j.ijhydene.2010.02.095

Ferreira, A. G., \& Borghetti, F. (2004). Germinação: Do básico ao aplicado. Porto Alegre: Artmed.

Formigheiri, F. B., Bonome, L. T. S., Bittencourt, H. von H., Leite, K., Reginatto, M., \& Giovanetti, L. K. (2018). Allelopathy of Ambrosia artemisiifolia on germination and growth of maize and soybean seedlings. Revista de Ciências Agrárias, 41(3), 151-160.

Fortes, A. M. T., Pereira, D.C., Senem, D., Spiassi, A., \& Tomazoni, D. (2011). Allelopathy of winter cover straws on the initial maize growth. Semina: Ciências Agrárias, 32(2), 577-582. https://doi.org/10.5433/ 1679-0359.2011v32n2p577

Kunz, K. D., Ficagna, T., Viecelli, C. A., \& Moreira, G. C. (2012). Alelopatia de extratos de crambe sobre sementes de milheto. Cultivando o Saber, 5(4), 63-71.

Menegusso, F. J., Simonetti, A. P. M. M. (2015). Alelopatia de crambe sobre milho. Revista Thêma et Scientia, $5(2), 169-174$.

Pereira, S., \& Simonetti, A. P. M. M. (2014). Alelopatia de extrato de crambe sobre a germinação e desenvolvimento inicial da soja. Revista Cultivando o Saber, 7(1), 67-72.

Pitol, C. (2008). Cultura do crambe. In M. S. Fundação (Ed.), Tecnologia e produção: Milho safrinha e culturas de inverno (pp. 85-88). Maracaju, MS.

Pitol, C., Broch, D. L., \& Roscoe, R. (2010). Tecnologia e produção: Crambe (p. 60). Maracajú: Fundação, MS.

RAS (Regra Para Análise de Sementes). (2009). Ministério da Agricultura, Pecuária e Abastecimento, Brasília.

Renosto, A., Vonz, K. M., Paiva, F. F., Marostica, T. F., \& Viecelli, C. A. (2014). Allelopathic effects of crambe extract the initial development of corn. Revista Cultivando o Saber, 7(2), 176-181.

Sampietro, D. A., Vattuone, M. A., \& Isla, M. I. (2006). Plant growth inhibitors isoleted from sugarcane (Saccharum officinarum) straw. Journal of Plant Physiology, 16(8), 837-846. https://doi.org/10.1016/ j.jplph.2005.08.002 
Spiassi, A., Fortes, A. M. T., Pereira, D. C., Senem, J., \& Tomazoni, D. (2011). Alelopatia de palhadas de coberturas de inverno sobre o crescimento inicial de milho. Semina: Ciências Agrárias, 32(2), $577-582$. https://doi.org/10.5433/1679-0359.2011v32n2p577

Vyvyan, J. R. (2002). Allelochemicals as leads for newherbicides and agrochemicals. Thetrahedron, 58(9), 1631-1646. https://doi.org/10.1002/chin.200233266

Wang, Y. P., Tang, J. S., Chu, C. Q., \& Tian, J. (2000). A preliminary study on the introduction and cultivation of Crambe abyssinica in China, an oil plant for industrial uses. Industrial Crops and Products, 12, 47-52. https://doi.org/10.1016/S0926-6690(99)00066-7

\section{Copyrights}

Copyright for this article is retained by the author(s), with first publication rights granted to the journal.

This is an open-access article distributed under the terms and conditions of the Creative Commons Attribution license (http://creativecommons.org/licenses/by/4.0/). 